\title{
EPMA 分析に基づくコンクリートの鉛直打継ぎの界面処理に関する考察
}

\author{
佐藤あゆみ ${ }^{* 1}$ 石山智 ${ }^{* 2}$ 山田寛次 ${ }^{* 2}$
}

*1 岐皁大学 工学部社会基盤工学科、日本学術振興会 特別研究員 $\mathrm{PD}$ ( \%501-1193 岐阜県岐皁市柳戸 1-1) *2 秋田県立大学 システム科学技術学部建築環境システム学科 ( $\bar{\top} 015-0055$ 秋田県由利本荘市土谷字海老ノ口 84-4)

\begin{abstract}
要旨：コンクリート構造物に生じる打継ぎ界面では、付着性能(強度と靭性)を向上させることが重要な課 題である。本研究では、その付着性能向上に向けた検討を深めるために、界面の処理目的として周知の脆 弱層除去と凹凸による嵌合強化以外にはないのか、改めて検討した。打継ざ界面近傍の EPMA 観察と破 壞鞁性試験を行った結果、先打ち部の界面処理による凹凸は、嵌合の強化と同時に後打ちで生じる脆弱層 の分散にも寄与して、付着性能向上に役立つことを明らかにした。また脆弱層の観察手法に関する新たな 提案を行うと共にそれを用いて脆弱層の形成機構の考察を行った。さらに界面に㧍ける付着性能を得るた めに必要な目荒し深さの定量的な根拠を示した。
\end{abstract}

キーワード：打継ぎ、界面、EPMA、ひび割れ、水酸化カルシウム、壁効果、骨材分布

\section{1. はじめに}

コンクリート構造物には打継ぎ面をはじめとするコン クリート界面が必然的に生じるが、これらコンクリート 界面では、構造耐力の低下に加え、漏水や鉄筋腐食の原 因となり耐久性の低下をもたらす。従って、硬化後のコ ンクリートと新しく打足すコンクリートとの付着性能を 向上させることは重要な課題である。特に、コンクリー 卜構造物の長期耐用が求められ、構造物にコンクリート を打足す補修や補強工事が増加している現在、その課題 解決の要求が高まっている。既往の研究では、打継ぎ 時の先打ち(旧側) コンクリートの表面の粗さ ${ }^{1)}$ や含水状 態 ${ }^{2)}$ に関する検討、さらに打継ぎ時の打設方法 ${ }^{3)}$ とそれ ら施工法 ${ }^{4)}$ が界面の付着性能に及ぼす影響について様々 な研究が行われている。

一方で著者らの研究 5) より、水和反応による化学的付 着力以外に、骨材の引抜け抵抗により発生する機械的な 付着力が、界面の力学特性値、特に勒性に大きな影響を 与えることが明らかになった。界面の機械的付着力を向 上させるためには、目荒しなどにより先打ちコンクリー 卜表面の凹凸を大きくし嵌合強化を図ることが有効であ るが、これはコンクリート標準示方書 ${ }^{6}$ や JASS57) に 既に示されている。また、打継時のブリーディング等に よって先打ち表面に生じるレイタンスや水酸化カルシウ ムなどの脆弱層は力学特性值を極度に低下させる要因と なる ${ }^{8)}$ ため、脆弱層除去の観点からも先打ちコンクリー トの表面処理は重要である。

しかし、骨材や脆弱層の分布状態を詳細に検討した研 究は見られず、表面処理などの方法や処理深さは未だ経 験的に行われている。以上より、本研究では界面近傍の
骨材や脆弱層の偏在を観察し、それらの分布が力学特性 值に与える影響を考察した。観察には電子プローブマイ クロアナライザー $(\mathrm{EPMA})$ と走査型電子顕微鏡を用い、 化学的特徴を中心に界面近傍と破面の考察を行った。さ らに、先打ち表面の処理が、上述の脆弱層除去と凹凸に よる嵌合強化以外に与える効果について検討した。

なお、これらの要因を調べるにあたり、骨材の沈降の 影響が小さい鉛直打継ざ界面を研究対象として採用した。

\section{2. 実験と力学特性値}

\section{1 実験}

（1）試験体作製

本実験では、骨材の種類と粗粒率を変えて、Table 1 に示す合計 6 種類の調合を使用した。また、Table 2 に 使用した骨材の名称と物性値を示す。調合は硬質砂岩砕 砂を使用した H シリーズ(Table 1(a))、普通砕砂を用 いたC 調合(Table 1(b))である。な㧍、全ての調合で セメントは普通ポルトランドセメント (密度 $3.16 \mathrm{~g} / \mathrm{cm}^{3}$ ) を使用し、混和剂はメタクリル酸ポリマー高性能 $\mathrm{AE}$ 減水剂を、セメント質量に対して 0.5 \% 使用した。各 調合のフレッシュ性状と力学的性質を Table 3 に示す。 また、本稿では代表的な 3 調合についてブリーディン グ率を測定し、その結果を Table 3 に示す。本実験では、 これらの調合を用いて下記 2 種類の試験体を作製した。

a）先打ち表面と打継ぎ界面の観察用試験体

Table 1(a)の 5 調合を用いて、表面処理を行う前の 先打ち側の表面観察用の試験体を作製した。強制練りミ キサーで混練した材料を鋼製型枠に打設し、24 時間後 に脱型を行った。脱型後は材齢 28 日まで標準養生を行 
Table 1 Mix proportions of concrete

(a) Mixtures of $\mathrm{H}$ types

\begin{tabular}{|c|c|c|c|c|c|c|c|c|c|c|c|}
\hline \multirow{2}{*}{ Symbol } & \multirow{2}{*}{$\mathrm{FM}$} & \multirow{2}{*}{$\begin{array}{l}\mathrm{W} / \mathrm{C} \\
(\%)\end{array}$} & \multirow{2}{*}{$\begin{array}{l}\mathrm{s} / \mathrm{a} \\
(\%)\end{array}$} & \multirow{2}{*}{$\begin{array}{l}\mathrm{S} / \mathrm{C} \\
(\%)\end{array}$} & \multicolumn{7}{|c|}{ Mass per unit volume $\left(\mathrm{kg} / \mathrm{m}^{3}\right)$} \\
\hline & & & & & $\mathrm{W}$ & $\mathrm{C}$ & $\mathrm{H}-\mathrm{SA}$ & $\mathrm{H}-\mathrm{SB}$ & $\mathrm{H}-\mathrm{GC}$ & $\mathrm{H}-\mathrm{GD}$ & $\mathrm{Ad}^{*}$ \\
\hline $\mathrm{H} 494$ & 4.94 & 50.0 & 43.0 & 225 & 178 & 356 & 540 & 263 & 347 & 736 & 1.78 \\
\hline H528 & 5.28 & 50.0 & 43.0 & 225 & 178 & 356 & 263 & 540 & 347 & 736 & 1.42 \\
\hline $\mathrm{H} 473$ & 4.73 & 50.0 & 43.0 & 225 & 178 & 356 & 540 & 263 & 736 & 347 & 1.78 \\
\hline $\mathrm{H} 425$ & 4.25 & 50.0 & 60.0 & 314 & 178 & 356 & 753 & 366 & 244 & 517 & 2.14 \\
\hline $\mathrm{H} 263$ & 2.63 & 50.0 & 100.0 & 225 & 299 & 598 & 906 & 441 & - & - & 0.00 \\
\hline
\end{tabular}

(b) Mixture of C type

\begin{tabular}{|c|c|c|c|c|c|c|c|c|c|}
\hline \multirow{2}{*}{ Symbol } & \multirow{2}{*}{$\mathrm{FM}$} & \multirow{2}{*}{$\begin{array}{l}\text { W/C } \\
(\%)\end{array}$} & \multirow{2}{*}{$\begin{array}{l}\mathrm{s} / \mathrm{a} \\
(\%)\end{array}$} & \multirow{2}{*}{$\begin{array}{l}\text { S/C } \\
(\%)\end{array}$} & \multicolumn{5}{|c|}{ Mass per unit volume $\left(\mathrm{kg} / \mathrm{m}^{3}\right)$} \\
\hline & & & & & $\mathrm{W}$ & $\mathrm{C}$ & $\mathrm{B}-\mathrm{S}$ & $B-G$ & $\mathrm{Ad}^{*}$ \\
\hline C & 4.93 & 51.4 & 43.0 & 215 & 182 & 354 & 762 & 1,041 & 1.74 \\
\hline
\end{tabular}

*Admixture

Table 2 Types and properties of aggregate

\begin{tabular}{l|l|r|r|r|r}
\hline Symbol & \multicolumn{1}{|c|}{ Types } & $\begin{array}{c}\text { size range } \\
(\mathrm{mm})\end{array}$ & $\begin{array}{c}\text { Finess } \\
\text { modulus }\end{array}$ & $\begin{array}{c}\text { Density } \\
\left(\mathrm{g} / \mathrm{cm}^{3}\right)\end{array}$ & $\begin{array}{c}\text { Water absorp- } \\
\text { tion (\%) }\end{array}$ \\
\hline $\mathrm{H}-\mathrm{SA}$ & Crushed sand & $\begin{array}{r}0 \sim 1.2 \\
1.2 \sim 5\end{array}$ & $\begin{array}{r}1.88 \\
4.19\end{array}$ & 2.64 & 1.48 \\
$\mathrm{H}-\mathrm{SB}$ & & $5 \sim 10$ & 6.00 & 2.68 & 1.01 \\
\hline $\mathrm{H}-\mathrm{GC}$ & Crushed stone & $10 \sim 20$ & 7.00 & & 1.97 \\
$\mathrm{H}-\mathrm{GD}$ & & $0 \sim 5$ & 2.34 & 2.49 & 2.49 \\
\hline $\mathrm{B}-\mathrm{S}$ & Crushed sand & $5 \sim 25$ & 6.70 & 2.59 & \\
\hline
\end{tabular}

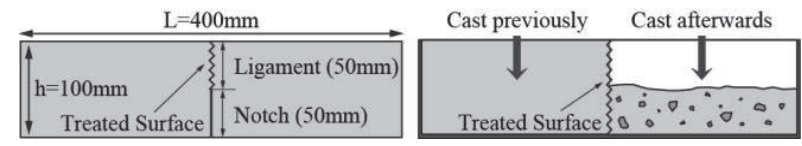

Fig. 1 Detail of specimen (left) and the method for producing specimen (right)

い、D-Dry 状況まで乾燥させた後、デシケータで保存 した。また、先打ち表面に目荒しを施した後、後打ちを 行い、打継試験体を作製した。打継ぎ試験体の作製法は 下記 b)で説明する。

b）破壊鞎性試験用の打継ぎ試験体

Table 1(a)、（b）すべての調合に対して、破壊鞎性試 験用の一体打ち試験体と鉛直打継ぎ界面を持つ打継ぎ試 験体を作製した。試験体名および特徵を Table 4 に示 す。試験体寸法は、 $100 \times 100 \times 400 \mathrm{~mm}$ の梁形とし概要 を Fig. 1 に示す。一体打ち試験体は材齢 28 日、打継ぎ 試験体は先打ち打設後 1 日または 28 日に打継ぎを行っ た 2 種類の試験体を作製した。試験体は各水準 3 体ず つ作製した。

打設は型枠に所定の材料を用いて一体打ちを行い、打 継ぐものは片側半分だ先打ちを行った。打継ぎ試験体 は24 時間後に脱型を行い、打継ぎまで水中養生を行っ た。所定の材齢時に打継ぎ界面に対して流水を掛けな がら、ワイヤブラシによって 2 分間目荒しを行なった。 目荒し処理後の打継ぎ界面は、材齢 1 日では粗骨材が 見える程度に、材齢 28 日では細骨材が見える程度にモ ルタルもしくは硬化セメントペーストが除去された。目 荒しを行なった後、Fig. 1 に示すように残る片側に打設 した。後打ち部の打設後は試験体によらず 28 日間の水 中養生を行なった。
Table 3 Properties of fresh and hardened concrete

\begin{tabular}{c|r|r|r|r|r|r|r}
\hline $\begin{array}{c}\text { Sym- } \\
\text { bol }\end{array}$ & $\begin{array}{c}\text { Slump } \\
(\mathrm{cm})\end{array}$ & $\begin{array}{c}\text { Air } \\
\text { content } \\
(\%)\end{array}$ & $\begin{array}{c}\text { Bleeding } \\
\text { rate } \\
(\%)\end{array}$ & $\begin{array}{c}\text { Density } \\
\left(\mathrm{g} / \mathrm{cm}^{3}\right)\end{array}$ & $\begin{array}{c}\text { Young's } \\
\text { modulus } \\
(\mathrm{GPa})\end{array}$ & $\begin{array}{c}\text { Compressiv } \\
\text { e strength } \\
(\mathrm{MPa})\end{array}$ & $\begin{array}{c}\text { Tensile } \\
\text { trength } \\
(\mathrm{MPa})\end{array}$ \\
\hline $\mathrm{H} 494$ & 10.0 & 2.9 & - & 2.40 & 22.76 & 46.3 & 3.8 \\
$\mathrm{H} 528$ & 5.0 & 1.8 & 2.15 & 2.41 & 24.47 & 45.1 & 3.4 \\
$\mathrm{H} 473$ & 1.0 & 2.1 & - & 2.40 & 24.29 & 46.5 & 3.6 \\
$\mathrm{H} 425$ & 1.5 & 3.7 & - & 2.36 & 23.51 & 43.0 & 3.9 \\
$\mathrm{H} 263$ & 19.5 & 2.5 & 6.88 & 2.25 & 18.82 & 47.5 & 3.5 \\
$\mathrm{C}$ & 21.0 & 3.0 & 2.85 & 2.31 & 26.99 & 42.0 & 3.5 \\
\hline
\end{tabular}

Table 4 Attributes of specimens

\begin{tabular}{|c|c|c|c|c|c|}
\hline \multirow[b]{2}{*}{ Name } & \multirow[b]{2}{*}{ Mix } & \multirow[b]{2}{*}{ Type } & \multirow{2}{*}{$\begin{array}{l}\text { Mold used for } \\
\text { placing joint }\end{array}$} & \multicolumn{2}{|c|}{ Curing duration } \\
\hline & & & & $\begin{array}{l}\text { at the cast } \\
\text { of joint }\end{array}$ & $\begin{array}{l}\text { at bend } \\
\text { test }\end{array}$ \\
\hline $\mathrm{H} 528 \mathrm{~N}$ & H528 & \multirow{5}{*}{ Monolith } & \multirow{5}{*}{-} & \multirow[t]{5}{*}{ 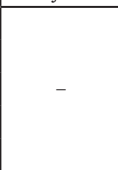 } & \multirow{5}{*}{28} \\
\hline $\mathrm{H} 494 \mathrm{~N}$ & H494 & & & & \\
\hline $\mathrm{H} 473 \mathrm{~N}$ & H473 & & & & \\
\hline $\mathrm{H} 425 \mathrm{~N}$ & H425 & & & & \\
\hline $\mathrm{H} 263 \mathrm{~N}$ & $\mathrm{H} 263$ & & & & \\
\hline H528R & H528 & \multirow{5}{*}{$\begin{array}{l}\text { Cast on } \\
\text { roughned } \\
\text { surface }\end{array}$} & \multirow{5}{*}{ Painted ply wood } & \multirow{5}{*}{1} & \multirow{5}{*}{29} \\
\hline H494R & H494 & & & & \\
\hline H473R & H473 & & & & \\
\hline $\mathrm{H} 425 \mathrm{R}$ & H425 & & & & \\
\hline H263R & $\mathrm{H} 263$ & & & & \\
\hline H528Rc & H528 & \multirow{5}{*}{ ditto } & \multirow{5}{*}{ ditto } & \multirow{5}{*}{28} & \multirow{5}{*}{56} \\
\hline H494Rc & H494 & & & & \\
\hline H473Rc & H473 & & & & \\
\hline $\mathrm{H} 425 \mathrm{Rc}$ & H425 & & & & \\
\hline H263Rc & $\mathrm{H} 263$ & & & & \\
\hline $\mathrm{CR}$ & \multirow{2}{*}{ C } & \multirow{2}{*}{ ditto } & \multirow{2}{*}{ ditto } & 1 & 29 \\
\hline $\mathrm{CRc}$ & & & & 28 & 56 \\
\hline $\mathrm{CSP}$ & \multirow{3}{*}{ ditto } & \multirow{3}{*}{$\begin{array}{l}\text { Cast on } \\
\text { non-treated } \\
\text { surface }\end{array}$} & Steel plate & \multirow{3}{*}{1} & \multirow{3}{*}{29} \\
\hline $\mathrm{CPW}$ & & & Painted ply wood & & \\
\hline $\begin{array}{l}\mathrm{CA} \\
\mathrm{CG}\end{array}$ & & & $\begin{array}{l}\text { Acrylic resin board } \\
\text { Sheet glass }\end{array}$ & & \\
\hline
\end{tabular}

また、打継ぎ時に目荒し処理を施さない試験体 (無処 理試験体）も作製した。それらは、先打ち部を作製する 際に使用する型枠の種類を変えている。使用した型枠材 料を Table 4 に併記する。

（2）載荷試験

所定の水中養生後、RILEM 推奨 ${ }^{9}$ ) の破壊勒性試験 を行い、荷重およびクリップゲージによって開口変位 (CMOD) を測定した。さらに自重の影響を防ぐためカ ウンターウェイトを取付け、ひび割れを集中させるため に載荷点下に高さ $50 \mathrm{~mm}$ の切欠き (Notch)を入れた状 態で載荷した。切欠きは、一体打ち試験体ではダイヤモ 
Table 5 Mechanical properties from bending test

\begin{tabular}{l|r|r|r|r}
\hline Name & $\begin{array}{c}\mathrm{Fb} \\
(\mathrm{MPa})\end{array}$ & Ratio of $\mathrm{Fb}$ & $\begin{array}{c}\mathrm{GF}_{(\text {WOF })} \\
(\mathrm{N} / \mathrm{mm})\end{array}$ & $\begin{array}{c}\text { Ratio of } \\
\mathrm{GF}_{(\text {WoF })}\end{array}$ \\
\hline H494N & 6.11 & 1.00 & 0.1254 & 1.00 \\
H528N & 6.34 & 1.00 & 0.1283 & 1.00 \\
H473N & 5.86 & 1.00 & 0.1329 & 1.00 \\
H425N & 5.01 & 1.00 & 0.1111 & 1.00 \\
H263N & 5.05 & 1.00 & 0.0558 & 1.00 \\
\hline H494R & 3.32 & 0.54 & 0.0236 & 0.19 \\
H528R & 3.02 & 0.48 & 0.0297 & 0.23 \\
H473R & 3.03 & 0.52 & 0.0169 & 0.13 \\
H425R & 3.00 & 0.60 & 0.0170 & 0.15 \\
H263R & 2.03 & 0.40 & 0.0114 & 0.20 \\
\hline H494Rc & 1.72 & 0.28 & 0.0068 & 0.05 \\
H528Rc & 1.94 & 0.31 & 0.0071 & 0.06 \\
H473Rc & 1.22 & 0.21 & 0.0050 & 0.04 \\
H425Rc & 1.85 & 0.37 & 0.0089 & 0.08 \\
H263Rc & 1.54 & 0.30 & 0.0070 & 0.12 \\
\hline CN & 4.77 & 1.00 & 0.1044 & 1.00 \\
\hline CR & 3.19 & 0.67 & 0.0279 & 0.27 \\
CRc & 2.59 & 0.54 & 0.0264 & 0.25 \\
\hline CSP & 1.80 & 0.38 & 0.0118 & 0.11 \\
CPW & 3.01 & 0.63 & 0.0271 & 0.26 \\
CA & 2.61 & 0.55 & 0.0158 & 0.15 \\
CG & 0.82 & 0.17 & 0.0014 & 0.01 \\
\hline
\end{tabular}

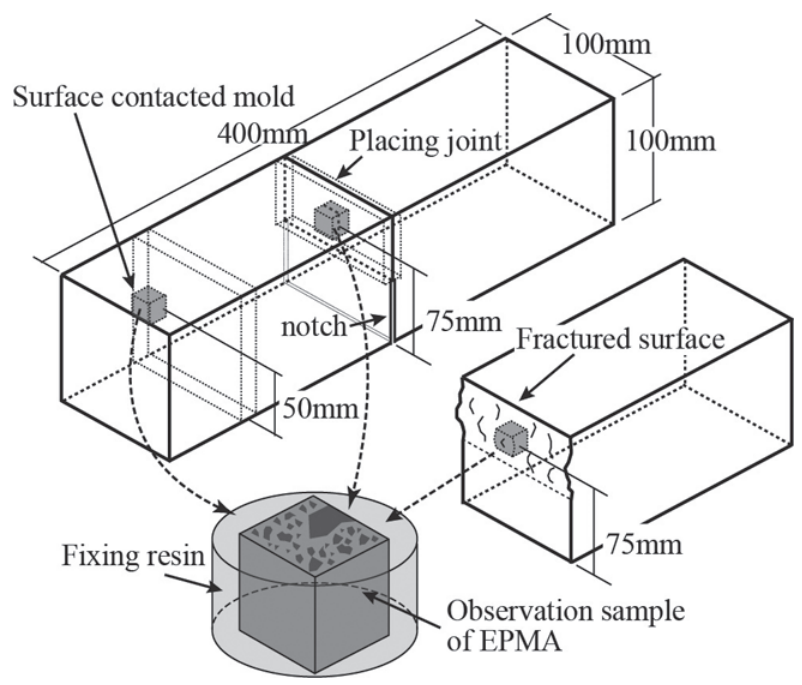

Fig. 2 Schematic illustration of sample preparation for analysis

ンドソーを用い、打継ぎ試験体では先打ち部にテープを 貼ることで入れた。

\section{2 実験結果}

Table 5 に破壊鞁性試験の結果を示す。表中で、試験 結果は各種類 3 体の平均值として示しており、Fbは 曲げ強度 $\mathrm{GF}_{(\mathrm{WOF})}$ は荷重-CMOD 曲線下から求めた破 壊エネルギーである。またTable 5 には各調合の一体 打ち試験体の值を 1.0 とした際の $\mathrm{Fb}$ と $\mathrm{GF}_{(\mathrm{WOF})}$ の比 率を示した。この表で、Fbの一体打ちに対する低下率 に注目すると、1 日打継ぎでは 4 7 割程度に、さらに 28 日打継ぎでは 2 5 割程度に低下することが分かる。 また $\mathrm{GF}_{\text {(WOF) }}$ も同様の傾向が認められるが、その低下率

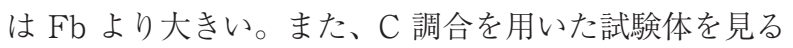
と、先打ち表面に目荒し処理を施した試験体より、無処 理で打継いだ試験体の方が、力学特性值が低い傾向にあ

\section{ることが分かる。}

\section{3. 打継ぎ界面近傍の脆弱層の化学的分析 3. 1 EPMA 解析}

本研究では、電子プローブマイクロアナライザー (EPMA : Electron Probe Micro Analyzer)を用いて、 $\mathrm{Ca}$ と Si 元素に対する面分析を行った ${ }^{10)}$ 。

本研究では、Fig. 2 に示すように観察対象位置(図中、 灰色の立方体)を 10〜 20mm 角程度にダイヤモンドソー

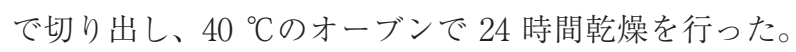
試料は Fig. 2 に示すように、底面から約 $50 \mathrm{~mm}$ もしく は $75 \mathrm{~mm}$ の位置を選定し、切り出した。Fig. 3 で乾燥 した試料をカーボン混入樹脂製の円柱型枠に固定した 後、型枠内にエポキシ樹脂を含浸させ 3 日間常温養生 した。樹脂の硬化後、ダイヤモンドスラリーを用いて鏡 面になるまで研磨を行った。なお、ダイヤモンドスラ リーは段階的に 9、6、1 $\mathrm{m}$ と細かくしている。また、 研磨した試料の表面にはカーボン蒸着を施し、観察を 行った。面分析の観察条件は加速電圧 $15 \mathrm{kV}$ 、照射電流

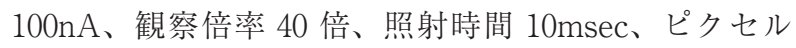
サイズ 1〜 $50 \mu \mathrm{m}$ 、ビーム径は $1 \mu \mathrm{m}$ である。また使用し た分光結晶は $\mathrm{Si}$ ：PETH、Si：TAP である。

\section{2 壁効果が界面近傍の骨材分布に及ぼす影響}

\section{(1) 先打ち表面の骨材分布に関する EPMA 観察}

Fig. 3 は先打ち表面(型枠に接触していた面)から約 $20 \mathrm{~mm}$ 程度の鉛直断面について EPMA を用いて面分析 を行った結果である。試料の左側が先打ち表面である。 なお、Fig. 3 はすべて表面処理を施していない状態であ る。Fig. 3(a) は H494 の Ca カラーマップ図であり、同 様に図 Fig. 3(b) は H494の Si カラーマップ図であり、 それぞれ白色に近づくにつれ、Ca もしくは Si 濃度が 高く表される。Ca 濃度が低くかつ Si 濃度が高く表さ れる位置は、二酸化珪素系骨材であると推定できるが、 径の大きな骨材が先打ち表面付近には少ない様子が分か る。他調合の $\mathrm{Ca}$ と $\mathrm{Si}$ カラーマップ図を Fig. 3(c)〜 (h) に示すが、これらの図からも先打ち表面付近で骨材が少 ないことが観察される。

次に、特定の闇值以上の濃度を持つ Si がすべて骨材 と仮定した場合、その Si の検出数を累計したものが骨 材分布と一致することになる。そのようにSiカラーマッ プ図から割り出した先打ち表面付近の骨材分布を Fig. 4 に示す。この図で各調合の骨材量を比較すると、先打ち 表面から $0.5 \mathrm{~mm}$ までの分布曲線はモルタルを含めて全 調合同じ勾配であるが、 $0.5 \mathrm{~mm}$ 以上では骨材の粒度分 布によって傾向が異なることが分かった。例えば H494 と比較して、小径の細骨材 H-SA が少ない H528 は先 打ち表面から $4 \mathrm{~mm}$ 程度まで骨材量が少なくなっている。 このように本稿の調合では、先打ち表面から約 $4 \mathrm{~mm}$ の 範囲まで骨材分布は均一ではないことが分かった。これ は、粗骨材周りのセメント粒子が受ける壁効果 ${ }^{11)}$ と同 じ作用が働いたものと考えられる。また壁効果から受け 


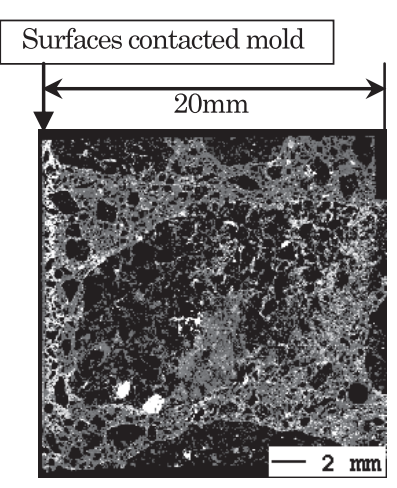

(a) Ca map of $\mathrm{H} 494$

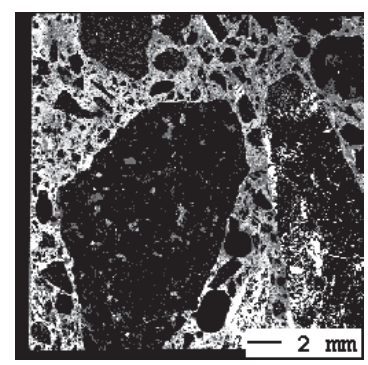

(c) Ca map of $\mathrm{H} 528$

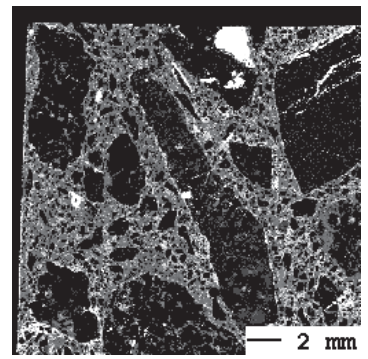

(e) Ca map of $\mathrm{H} 473$

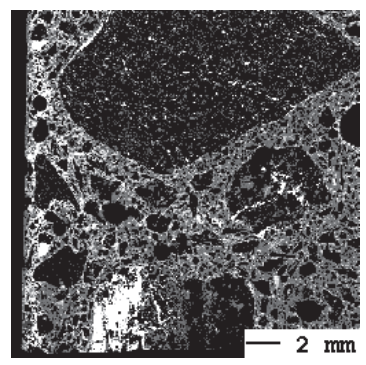

(g) Ca map of $\mathrm{H} 425$

$\mathrm{Ca}, \mathrm{Si}$ Level

$$
\begin{array}{llllll}
0 & 200 & 400 & 600 & 800 & 1000
\end{array}
$$

Fig. 3 Aggregate distribution observed by color maps ( $\mathrm{H}$ types)

る影響は調合の骨材量や骨材粒度分布、特に細骨材の差 によって異なると言える。

\section{（2）界面近傍の骨材分布に関する EPMA 観察}

Fig. 5 は先打ち部の表面に目荒しを施し、粗骨材ま で露出させた面に、後打ち部を打継いだ界面近傍の EPMA 観察結果である。この図から、先打ち部の骨材 量が少ない領域は目荒しによって除去され、粗骨材が界 面に存在していることが分かる。しかし打継ぎ時に、先

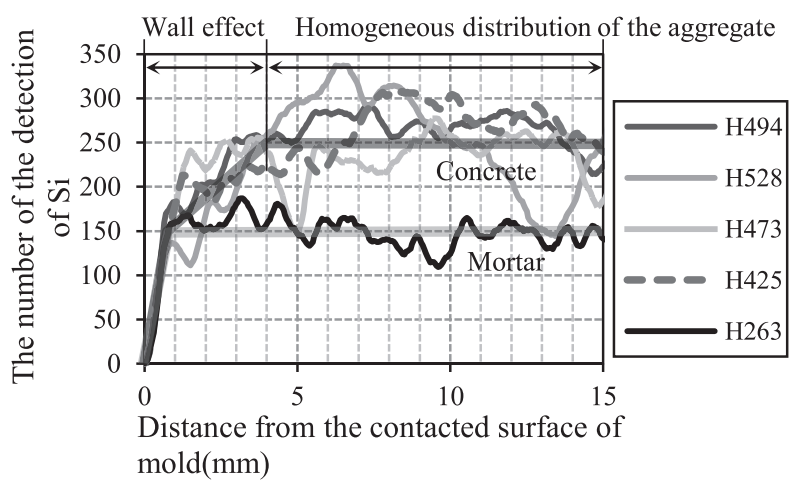

Fig. 4 Aggregate distribution observed by Si concentration

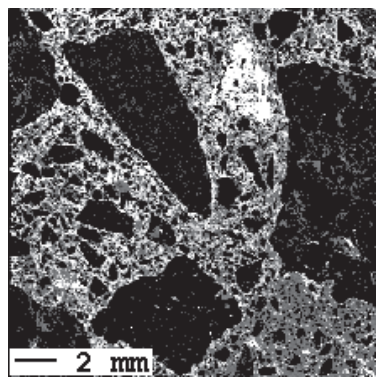

(a) Ca map by EPAM analysis

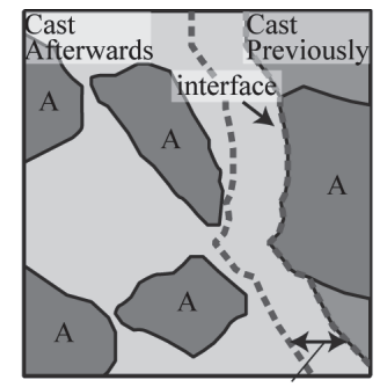

The region where wall effect emerges

(b) Schematic illustration
Fig. 5 Wall effect emerged near the interface (H494R)

打ち部が型枠となり後打ち部に壁効果が働き、界面から $2 \mathrm{~mm}$ 程度は径の大きい骨材が少ない状態となっている。 すなわち、Fig. 5 のように適切に先打ち表面を処理して も後打ち側の骨材分布が内部と異なるために、物理的な 付着力は低下することが示唆された。

3. 3 ブリーディング水による界面近傍の $\mathrm{CH}$ 生成 (1) 先打ち表面の $\mathrm{CH}$ 分布に関する EPMA 観察

Fig. 3(a)の H494、同図 (g) の H425 は、それぞれ先 打ち部の表面近傍の Ca カラーマップ図であるが、先打 ち表面の $\mathrm{Ca}$ 濃度が明らかに内部より高く、これは水 酸化カルシウム (以下、CH) であると予想される。コン クリートは型枠に沿ってブリーディング水が上昇しや すい ${ }^{12)}$ ため、その水みちに由来する $\mathrm{CH}$ が析出したと 考えられる。 $\mathrm{CH}$ は粗骨材周りの遷移帯の主要物質であ

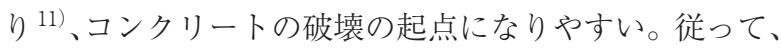
Fig. 3 のように界面近傍に生成すれば界面の付着力低下 の原因となるため、適切に除去する必要がある。

\section{(2) 界面近傍における $\mathrm{CH}$ 分布の特徵}

Fig. 6 は走査型電子顕微鏡 $(\mathrm{SEM})$ で観察した反射電 子像(BSI)であり、先打ち部の表面に目荒しを施し、細 骨材まで露出させた面に打継いだ界面近傍の観察結果で ある。なお、反射電子像は平均原子番号が高い物質ほ ど、高い輝度で表現されるため、 $\mathrm{CH}$ 、セメントペースト、 骨材、空隙の順に輝度が高い。この図より、Fig. 3(a)で 


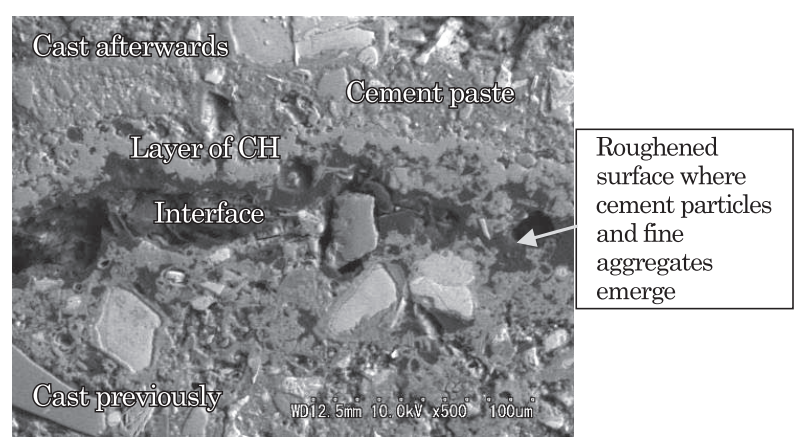

Fig. 6 BSI of H494R near interface

見られた先打ち側の $\mathrm{CH}$ 層は、目荒しによって除去さ れていることが分かる。しかし、界面近傍の後打ち側を 観察すると先打ち側に接するように、 $\mathrm{CH}$ 層が生成した ことが確認できる。これは、Fig. 7 に示すように打継ぎ 時に先打ち側が型枠となり、打継ざ界面に沿ってブリー ディング水が上昇したためである。特に Fig. 4 の分布 のように界面近傍では局所的に骨材が少ないために、骨 材が邪魔しない分、水みちが生じやすいと考えられる。

しかしながら、Fig. 5 に見るように先打ち側の凹凸が 大きい場合には、ブリーディング水が分散するため、後 打ち側の $\mathrm{CH}$ 層も生成されにくいと言える。

\section{4 鉛直打継ぎ界面近傍の脆弱層の形成機構}

前述の観察結果を基にして、先打ち部の材齢別に、打 継ざ界面近傍の脆弱層の形成機構について考察を行っ た。まず Fig. 8(a)の先打ち部の材齢 1 日で目荒しを施 し打継ぎを行う場合、先打ち側の硬化が不完全で、目荒 しされ易く骨材が露出しやすいため凹凸が大きくなる。 そのため、機械的嵌合が向上するだけでなく、ブリーディ ング水も分散し、連続した $\mathrm{CH}$ 層が生成しにくいと考 えられる。さらに、未水和セメントの残存率が高いこと も相俟って化学的付着も比較的高いと考元られる。

一方で Fig. 8(b)の先打ち部の材齢 28 日で目荒しを 行う場合、先打ち側の硬化が進行しており、目荒しし難 いことから凹凸が小さくなるため、機械的嵌合が低下す る。さらに、ブリーディング水の集中によって連続した $\mathrm{CH}$ 層が生成し、残存する未水和セメントが少ないこと もあり化学的付着力は激減することになる。

いずれにせよ、材齢や目荒しの深さに関係なく、壁 効果によって後打ち側に骨材量が少ない領域が生じる。 しかしながら、先打ち側の処理を適切に行わない場合、 Fig. 8(b)に示すように、CH 層を除去できないだけでな く、骨材が少ない領域がさらに拡張するため、界面の付 着強度向上を図る場合は、先打ち表面を最低でも $4 \mathrm{~mm}$ 以上深く削る必要があると言えよう。

\section{4. コンクリート界面のひび割れ伸展経路}

\section{1 反射電子像によるひび割れ伸展経路の観察}

打継ざ界面近傍のひび割れ伸展経路を観察するため、 破壊靯性試験で分離した破面を切断し側面方向から反射

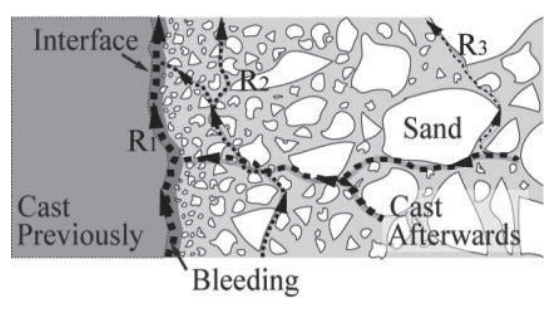

Fig. 7 Modeled bleeding mechanism near interface ${ }^{8)}$

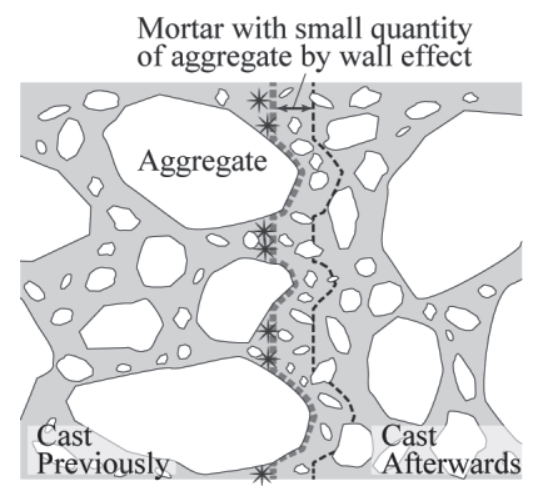

(a) The age of substrate (cast previously) is 1day when jointed

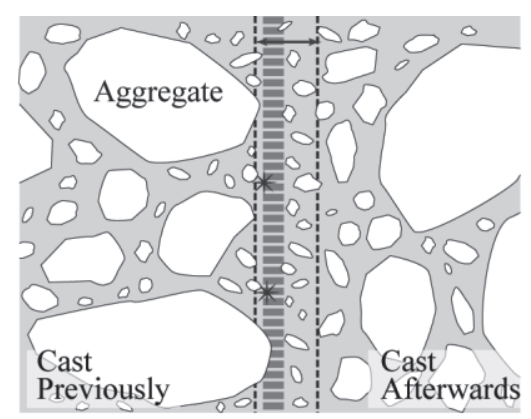

* Unhydrated cement which remains near interface IIIII Calcium hydroxide generated by bleeding

(b) The age of substrate (cast previously) is 28 days when jointed

Fig. 8 The mechanism of formation of the weak layer near the vertical placing joint in concrete

電子像による観察を行った (Fig. 2 参照)。Fig. 9(a)、(b) に H494R とRc との 2 種類の観察結果を示す。両図で 下方が先打ちコンクリートである。

Fig. 9(a)の H494R (1 日打継ぎ) は先打ち部分にひび 割れが伸展しており、微小な細骨材周りを迂回するよう に破壊されていることが確認できる。このように、ひび 割れは骨材間の最短距離を伸展する傾向があるが、先 打ち材齢が 28 日で打継いだ試験体の場合は必ずしもそ の傾向に合致するわけではなく、Fig. 9(b)の H494Rc (28 日打継ぎ) はひび割れのほとんどが打継ぎ界面に伸 展し、剥離破壊であった。また剥離した面にはセメン トペーストより輝度の高い $\mathrm{CH}$ の層が存在しているが、 ブリーディング水によって局部的に水セメント比が高く なったためと予想され、Fig. 8 のモデルと対応している ことが分かる。 


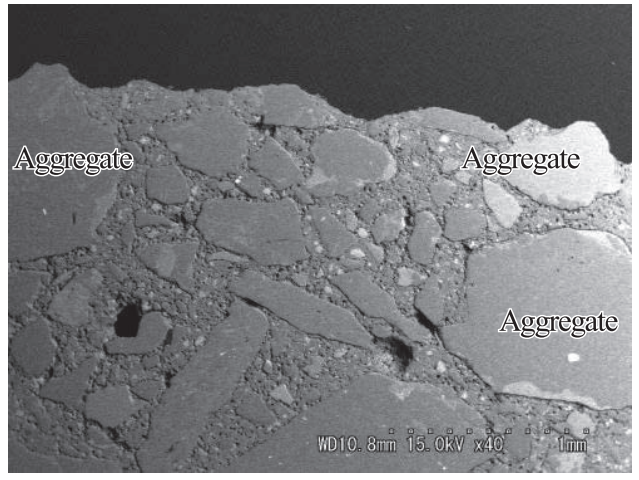

(a) BSI of H494R near fractured surface

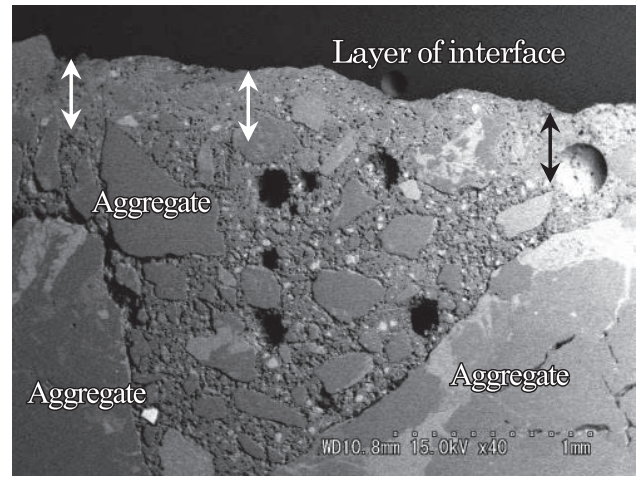

(b) BSI of H494Rc near fractured surface

Fig. 9 BSI photos from fractured surfaces

\section{4. $2 \mathrm{Ca} / \mathrm{Si}$ 比に関する考察}

(1) $\mathrm{Ca} / \mathrm{Si}$ マップの提案

Fig. 10（a）はアクリル樹脂板を用いて作製した打継ぎ 試験体の破面である。左が Ca、右が $\mathrm{Si}$ のカラーマッ プ図である。この図から骨材周りではなく、打継ぎ界面 近傍で破壊していることが分かるが、CH の存在の有無 などは不明瞭である。この傾向は、前掲の Fig. 9 の反 射電子像でも同様であり、破壊要因をより明確に確認で きる手法が必要である。

そこで、本稿では EPMA による定量分析から得られ た Fig. 10(a)の Ca および Si 濃度から、Ca/Si 比を計 算した。一般に CSH ゲルの組成は $\mathrm{C}_{3} \mathrm{~S} 2 \mathrm{H} 4$ 前後と言わ れているが、 $\mathrm{CaO}$ と $\mathrm{SiO}_{2}$ のモル比がこの 1.5 を中心 に 1 から 2 まで変化するとすれば、 $\mathrm{Ca} / \mathrm{Si}$ 質量濃度比 は 2.14 を中心に 1.43〜2.85 程度にばらつくことにな る ${ }^{13)}$ 。そこでこの比が 1.0 3.0 の範囲で CSH ゲルを 示していると仮定し、3.0 を超えるものが $\mathrm{CH}$ の存在確 率の高い脆弱層、1.0 未満のものは二酸化珪素系の骨材 又はポロシティであるとする。この結果を図示したもの がFig. 10(b)であり、ここでは 1.0 未満を白色、1.0〜 3.0 を灰色、3.0 を超えるものを黒色で表示している。 Fig. 10（b）を見ると破面には $\mathrm{CH}$ の層が随所に存在して いることが分かる。

(2) $\mathrm{Ca} / \mathrm{Si}$ マップを用いたひび割れ経路に関する考察

Fig. 11(a)〜 (c) は無処理試験体の破面であり、界面近 傍で破壊した位置を $\mathrm{Ca} / \mathrm{Si}$ マップによって表した図で

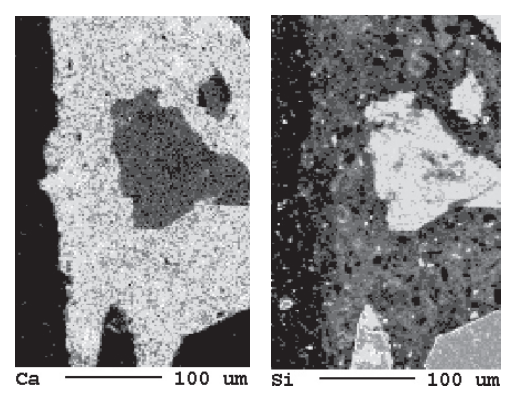

(a) EPMA photos (left : Ca, right : Si)

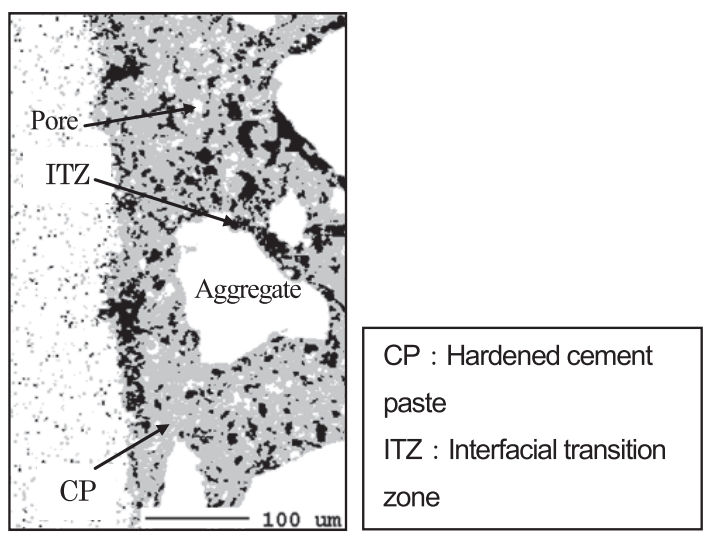

(b) Ca/Si map

Fig. $10 \mathrm{Ca} / \mathrm{Si}$ map of Specimen-CA (Cast previously)
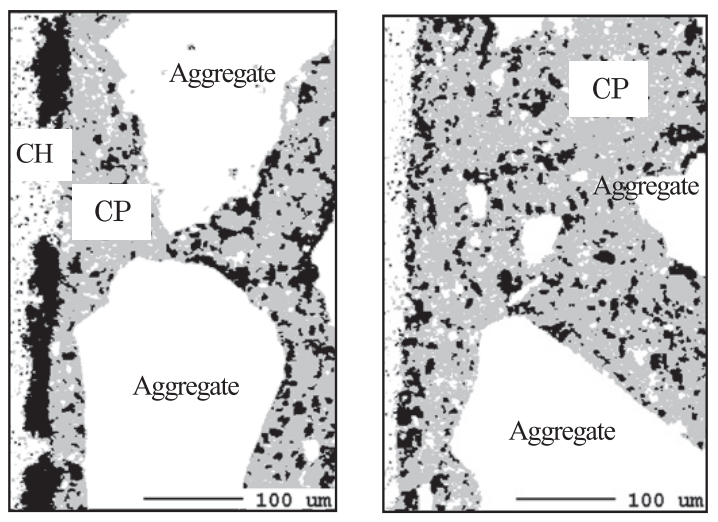

(a) Specimen-CA (Cast previously) (left)

(b) Specimen-CG (Cast afterwards) (right)
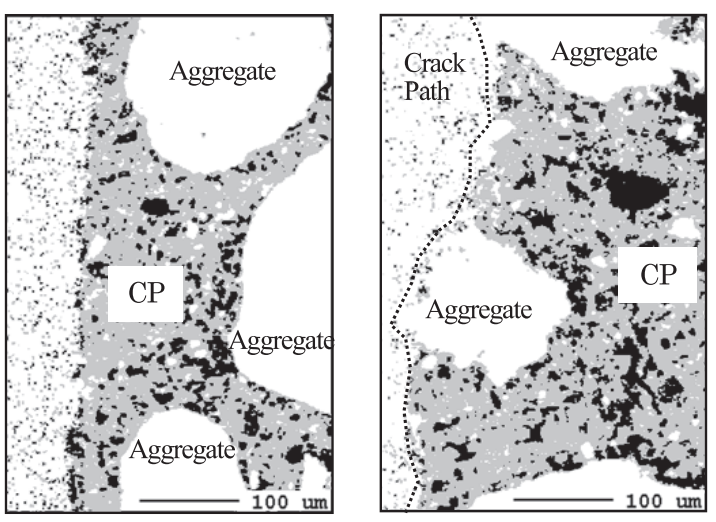

(c) Specimen-CSP (Cast previously) (left)

(d) Specimen-CR (Cast previously) (right)

Fig. $11 \mathrm{Ca}$ /Si maps from EPMA analysis 
ある。Fig. 11(a)は CA、Fig. 11(b) はCG の破面であり、 これらの $\mathrm{Ca} / \mathrm{Si}$ マップでは明確な $\mathrm{CH}$ の固まりが認め られ、特に CA は $40 \mu \mathrm{m}$ 厚程度の $\mathrm{CH}$ が確認できた。 このように、適切に脆弱層を除去しない場合、 $\mathrm{CH}$ 層に ひび割れが伸展することが示された。一方で、Fig. 11(c) の CSP では明確な $\mathrm{CH}$ の層は確認できなかったが、こ の場合も骨材周りに破壊は至らず、界面を直線的に破壊 していた。Fig. 11(a)〜 (c) の結果は、肉眼では同様の破 壞状態に見えたが、このように $\mathrm{Ca} / \mathrm{Si}$ マップで表現する ことで、CH の分布が異なることが分かった。これらは すべて同調合であり、目荒しを施さない無処理試験体で あるが、CH の分布状態に差が生じる理由は、型枠の微 妙な凹凸や吸水や、型体材質の親水性や撥水性が型染面 での水みちの大きさ等に影響するためだと考えられる。

Fig. 11(d) は CH 層を目荒しで除去した後に打継いだ CR の破面であり、ひび割れが細骨材を过回しながら伸 展したことが分かる。また、無処理試験体のように、破 壊面に明確な $\mathrm{CH}$ も見られず、脆弱部除去の効果が確 認できた。このように、目洗し処理を施すことで、材料 内部へひび割れ伸展経路を誘導でき、部材全体の力学的 な性能も向上すると考えられる。

\section{5. まとめ}

本稿では、打継ぎ界面近傍を EPMA によって観察し、 脆弱層の観察手法に関する新たな提案を行うとともにそ れを用いて脆弱層の形成機構の考察を行った。その結果 界面処理に従来論じられてこなかった目的があることを 明らかにした。さらに界面に打ける付着性能を得るため に必要な目荒らし深さの定量的な根拠を示した。

本稿による新しい知見は以下の通りである。

（1）脆弱層とその観察手法

目荒らしの主目的として脆弱層の除去と骨材を露出さ せて嵌合を強化させるためであることがよく知られて いる。本稿では、EPMAによる観察結果を画像解析し、 概ね $\mathrm{Ca} / \mathrm{Si}$ 質量濃度比が 3.0 程度の部分を脆弱層と推 定した。その範囲を除去した試験体で付着性能の向上が 確認されたことから、抄抄むね脆弱層の判定は妥当で あったと考えられる。また Si の面分布量に着目するこ とで壁効果による細骨材が少ない領域の範囲が明確に区 別できることを示した。

(2) 界面処理の目的

型枠が水みちとなり、特に目荒しを施さずに打継ぎを した場合には水酸化カルシウムの厚い層ができる。しか し、目荒しによって適切に処理した部分に打継ぎをする と、先打ち部表面を伝って後打ち部からブリーディング が生じるにも拘わらず脆弱層は形成しなかった。先打ち 部の凹凸によって脆弱層が分散したためであると考元ら れる。つまり先打ち部の凹凸は嵌合の強化と同時に後打 ちで生じる脆弱層の分散にも寄与している。

(3) 目荒らし深さの定量的な根拠

上記 (1)、（2）により、界面の付着性能を確保するため
には、最低でも先打ち表面の骨材量が少ない領域である $4 \mathrm{~mm}$ 以上深く削る必要がある。

\section{謝辞：}

本研究は筆頭著者の博士論文の一部をなすもので、副 査の小林淳教授(秋田県立大学システム科学技術学部)、 六郷恵哲教授 (岐阜大学工学部) ほか多くのご助力を頂い た。ここに記して感謝の意を表す。

\section{参考文献：}

1）槙谷貴光、香取慶一、林静雄：コンクリート打継ぎ 面に扔ける表面粗さの評価とせん断力伝達能力に関 する実験研究、コンクリート工学年次論文報告集、 Vol. 17、No. 2、pp. 171-176 (1995)

2）林承燐ほか：新・旧コンクリートの養生方法が打継 ぎ部の付着性状に及ぼす影響、コンクリートの配合 および打継ぎ方向が打継ぎ部の付着性状に及ぼす影 響、コンクリート工学年次論文集、Vol. 24、No. 1、 pp. 1053-1058 (2002)

3）林承燦ほか：コンクリートの配合掞よび打継ぎ方向 が打継ぎ部の付着性状に及ぼす影響、コンクリート 工学年次論文集、Vol. 25、No. 1、pp. 557-562（2003）

4）足立一郎、小林一輔：ショットブラストを利用した 新旧コンクリートの打継ぎ工法に関する研究、土木 学会論文集、第 373 号／VI-5、pp. 64-73（1986）

5）佐藤あゆ久、山田寬次、石山智：引張軟化曲線と引 抜だぼモデルによる新旧コンクリート界面の強度と 靯性の関係についての考察、日本建築学会構造系論 文集、第 74 巻、第 637 号、pp. 417-424（2009）

6）土木学会（編）：2007 年度制定 コンクリート標準 示方書【施工編】、pp. 130-137 (2008)

7）日本建築学会 (編)：建築工事標準仕様書・同解説 JASS5 鉄筋コンクリート工事 13 版、pp. 267-269 (2009)

8）佐藤あゆみ、山田寛次、石山智：高炉スラグ細骨材 を用いたコンクリート打継ざ界面の力学特性值向上 に関する破面解析的考察、セメント・コンクリート 論文集、No. 64、pp. 272-280（2011）

9) RILEM Draft Recommendation: Determination of the Fracture Energy of Mortar and Concrete by Means of Three-point bend Tests on Notched Beams, Materials and Structures, Vol. 18, No. 106, pp. 285-290 (1985)

10）土木学会（編）：コンクリート技術シリーズ 69 硬 化コンクリートのミクロの世界を拓く新しい土木学 会規準の制定-EPMA 法による面分析方法と微量 成分溶出試験方法について-、pp. 55-88（2006）

11）川村満紀、S. Chatterji：コンクリートの材料科学、 森北出版、pp. 81-93（2002）

12）犬飼利嗣ほか：視覚的評価方法によるモルタル中 のブリーディング挙動に関する基礎的研究、コン 
クリート工学年次論文集、Vol. 25、No. 1、pp. 545-

$550(2003)$
13) H. F. W. Taylor : Cement Chemistry, pp. 118-119 (1997)

\title{
A DISCUSSION BASED ON EPMA ANALYSIS ON THE TREATMENT FOR VERTICAL PLACING JOINT OF CONCRETE
}

\author{
Ayumi SATOH ${ }^{* 1}$, Kanji YAMADA ${ }^{* 2}$ and Satoru ISHIYAMA ${ }^{* 2}$ \\ *1 GIFU UNIVERSITY, Dept. of Civil Engineering, Faculty of Engineering, JSPS fellow (1-1, \\ Yanagido, Gifu-shi, Gifu 501-1193, Japan) \\ *2 AKITA PREFECTURAL UNIVERSITY, Dept. of Architectural and Environment Systems, \\ Faculty of Systems Science and Technology (84-4, Ebinoguchi, Tsuchiya, Yurihonjyo-shi, Akita \\ 015-0055, Japan)
}

\begin{abstract}
The enhancement of structural performance of placing joint in concrete is one of the most critical issues for concrete structure in terms of interfacial bonding strength and toughness. There are well-known purposes of surface treatment, such as a removal of the weak layer and a roughening of the surface for the better adhesion. The authors re-investigated whether or not there are any other reasons in an attempt to achieving high structural performance for the joint.

The authors conducted fracture toughness test with concrete specimens including observations of the placing joint with Electron Probe Microscope Analyzer. The observations made it clear that there is another important reason of making the rough surface, which is the dispersion of the weak layer generated by bleeding from the concrete placed afterwards along the substrate concrete.

The authors proposed new methods of image-analysis; one is observing a weak layer by emphasizing the quantity of $\mathrm{Ca}$ and another is revealing a wall effect of aggregate by accumulating the quantity of Si near the interface. These two methods not only helped reveal the mechanisms of formation of the weak layer but also helped determine quantitatively the minimum depth of roughening the surface for the vertical placing joint.
\end{abstract}

KEY WORDS : Placing joint, Interface, EPMA, Crack, Calcium hydroxide, Wall effect, Distribution of aggregate 